\title{
5章 音楽と高品質化
}

キーワード : 音楽, 高品質化, スーパーハイビジョン, 3 次元音響, 22.2 マルチチャネル音響, 音響信号処理

\section{1.まえがき}

音響技術の進歩と発展においては，音楽の収音再生がそ のモチベーションの一つとなっている．音を記録再生する 機器の黎明期にエジソンが発明したフォノグラフの特許に は，その用途として，速記の記録や耳で聞く書籍とともに， 音楽の記録再生が記されている. また，20世紀前半にベル 研究所では, 多数のマイクロホンとスピーカを用いた立体 音響の伝送技術の実験を，ストコフスキー指揮フィラデル フィア管弦楽団の演奏を用いて行っている.

レコードやCDをはじめとするパッケージメディアにお いて音楽が重要であるのはもちろんのこと, 放送において も, 放送開始時期のモノ (1ch) 音声から, アナログ放送で 用いられた $2 \mathrm{ch}$ ステレオ, デジタル放送の $5.1 \mathrm{ch}$ サラウンド, $8 \mathrm{~K}$ スーパーハイビジョンの $22.2 \mathrm{ch}$ マルチチャネル音響へ と発展を続ける中, 音楽は常に放送システムの魅力を示す 上で欠かせないコンテンッであり，その制作においては， 素材を高品質化なまま扱える信号処理技術が重要な役割を 果たしてきたそそこで本稿では，放送やパッケージメディ アなど，音楽コンテンツの制作にかかる技術を，特に音楽 の高品質化の観点から概観するとともに，近年のトピック として, $8 \mathrm{~K}$ スーパーハイビジョンの音響方式である 22.2 マ ルチチャネル音響に関連する音響信号処理技術を中心に紹 介する。

\section{2. 高品質化の要素}

音響技術の高品質化にはさまざまな要素が存在するが， ここではHarry F. Olsonが提案した下記の5項目について 考えてみたい.

(1)雑音が低いこと

(2)ダイナミックレンジが広いこと

(3) 周波数帯域が広いこと

(4)音の定位が明確であること

(5)音の空間的な印象を再現すること

$\dagger$ NHK 放送技術研究所

"High Quality Audio Signal Processing for Music" by Kazuho Ono (Science \& Technology Research Laboratories, NHK, Tokyo)
このうち，(1)〜(3)については，マイクロホンなどの収音 装置や，テープレコーダなどの記録装置，スピーカなどの 再生装置の性能向上が図られてきた。 これらのうち, 劣化 の要因の一つであった記録装置については, NHK技研が 世界で始めて開発したPCM 録音技術が品質の改善に与え たインパクトが大きく, 大半の音響記録伝送機器をアナロ グ方式からディジタル方式に移行させた.

具体的にはディジタル方式で充分なビット深度を確保する ことにより，(1)の雑音のうち量子化雑音の低減と(2)のダイナ ミックレンジを確保でき, (3)周波数帯域についても, デジ タル放送で用いられるサンプリング周波数 $48 \mathrm{kHz}$ や，コンパ クトディスクで用いられるサンプリング周波数 $44.1 \mathrm{kHz}$ など により，ナイキスト周波数が一般に人間の聴覚の上限とい われる $20 \mathrm{kHz}$ をカバーした。 近年では, 自然界や楽器音に は存在する $20 \mathrm{kHz}$ を上回る周波数帯域までカバーする機器 が広まりつつある。なお，これらの品質を確保するために は, 収音・再生機器, $\mathrm{A} / \mathrm{D} \cdot \mathrm{D} / \mathrm{A}$ 変換の品質が充分に高 いことが前提であることはいうまでもない.

また，音の空間性にかかわる(4)と(5)について，音響シス テムはモノ (1ch) 再生から始まり，ステレオ $(2 \mathrm{ch}), 5.1$ サ ラウンド $(5 \mathrm{ch})$ まで, 水平方向にチャネルを増やすことで 進歩を図ってきた５.1サラウンドがデジタル放送や映画を はじめとして広く用いられるフォーマットとして普及して いるのは，周知の通りである.

一方, 現実の音空間では, 音は前後, 左右, 上下のあら ゆる方向から到来するものであり, 人間の聴覚もまた, 視 覚と異なり前後左右から到来する音を知覚することが可能 である。その意味において，(4)と（5)はまだ発展途上にある ともいえる. 現在も研究開発が進み, 一部実用化も進み始 めている 3 次元音響技術は，この音響事象の空間性を取り 扱うための技術である。そこで次章以降，3次元音響に関 連した信号処理技術について述べる。

\section{3次元音響に関連した信号処理}

\subsection{3 次元音響方式の分類}

3 次元音響技術は, 空間内の 1 点を基準に方向の異なる 複数チャネルを設置し，その各チャネルが音の到来方向と 


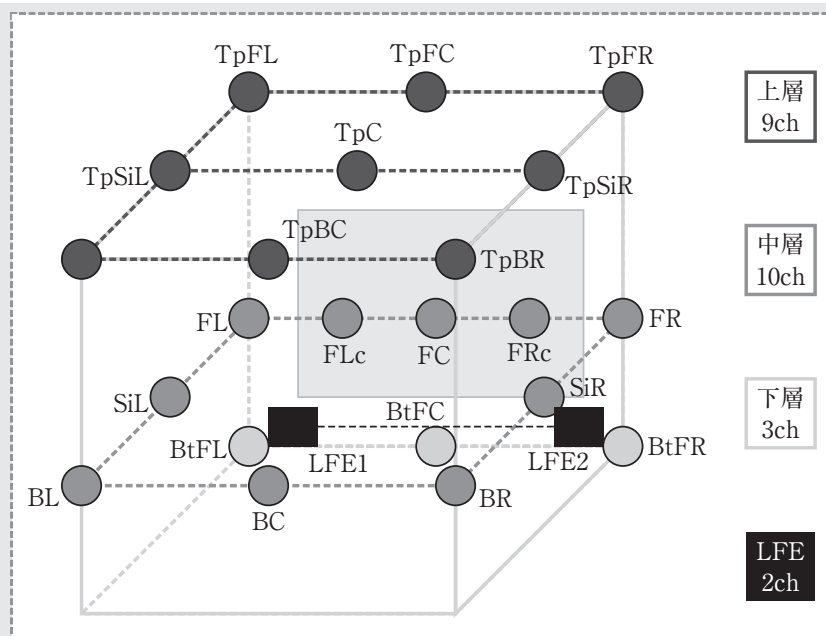

図 1 22.2マルチチャネル音響

1 対 1 に対応するマルチチャネル方式, 複数チャネル全体で 音場を表現する音場再現方式に大きく分けられる．詳しく は本誌 2014 年 8 月号の特集「立体音響技術」を参照されたい.

いずれの方式においても，(4)の定位の実現，5の音響空 間印象の実現の双方において，チャネルを高さ方向にも配 置することがキーとなる．

このうちマルチチャネル音響はすでに実用化も進み，こ れまでにさまざまなフォーマットが提案され，主要なもの が针告ITU-R BS.2051に記載されている。2016年に試験放

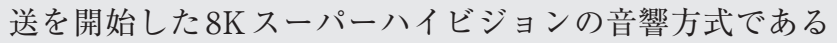
$22.2 \mathrm{ch}$ 音響 (図 1) は，高精細な大画面用の音響システムと して主として以下の要求条件を定めた, ITU-R 钓告 BS.1909を満たす高品質な音響再生を可能とするフォー マットである。

（1）聴取位置を取り囲む全方向からの音の到来が再現可 能なこと

(2) 高品質な 3 次元音響空間印象 (包み込まれ感)を再現 できること

（3）スクリーン上任意の位置での映像と音像の方向が一 致すること

(4) 広い視聴範囲をもつこと

以下， $22.2 \mathrm{ch}$ 音響を中心に，3次元音響に用いられる信 号処理技術について紹介したい.

\section{2 収音}

収音については，通常の 2 チャネルステレオや， 5.1 サラ ウンドの収音と同様に，全体の音を捉えるメインマイク， 残響や背景音の収音, 広がり感を表現するアンビエンスマ イクにより構成されることが多い。この場合，収音した各 マイクロホンの音を各チャネルに割当てて, 方向性を表現 するために 3 次元パンニング装置が用いられる．詳細につ いては解説1)を参照されたい.

一方，限られた狭い空間で収音する場合などは，基本的 には空間内の 1 点を囲むように，チャネルの方向に合わせ

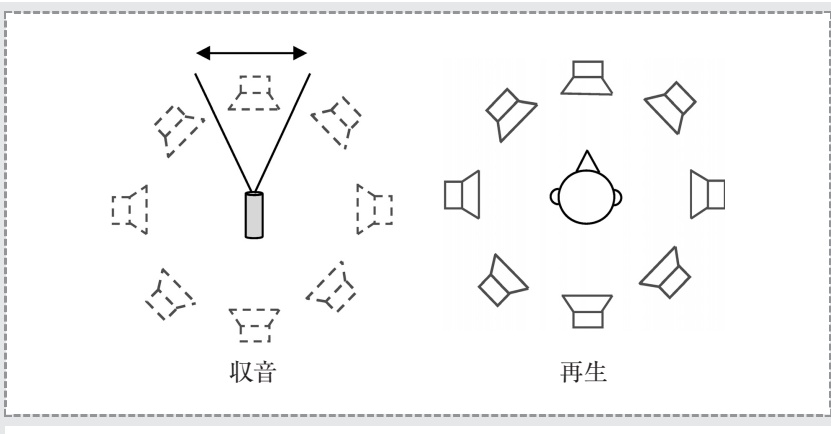

図2 ワンポイント収音の考え方

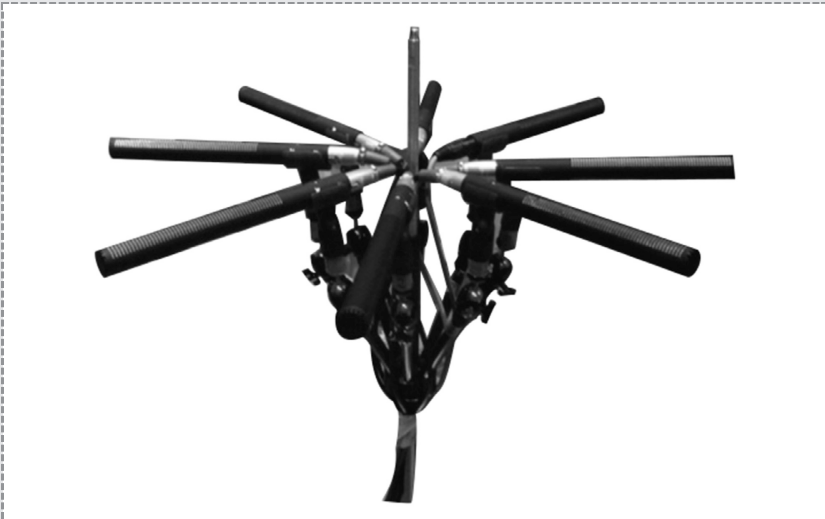

図3 ショットガンマイクロホンアレイ

て方向別に収音するワンポイントマイクロホンが考えられ る(図2)。この場合， $22.2 \mathrm{ch}$ 音響などのように，隣接する チャネル間の角度が狭いシステムでは，チャネル間のセパ レーションを確保するためには, より狭い指向性が求めら れる。

一般にマイクロホンの指向性制御では, 全指向性の（指 向性を持たない) 素子を用いたマイクロホンアレイにより 指向性合成を行うことが多い。このようなマイクロホンア レイを用いて可聴帯域である $20 \mathrm{~Hz} \sim 20 \mathrm{kHz}$ の帯域をカ バーする場合，波長の長い低周波数帯域 (以下，低域)にお いて指向性を確保するにはマイクロホンアレイ全体の大き さが必要である一方，波長の短い高周波数帯域 (以下，高 域）はマイクロホン間隔を狭める必要がある。このため, 広い帯域をカバーするようなマイクロホンアレイを構成す るには，マイクロホン間隔の狭い条件で，大きなアレイを 構成する必要があり，結果として極めて多数のマイク素子 を配置する必要がある。

一方，図3のように $22.2 \mathrm{ch}$ 音響のチャネルの方向が固定 していることに着目し，チャネルの方向に狭指向性の ショットガンマイクロホンを設置すれば, 高域ではショッ トガンマイクロホンの単体の狭指向性が利用可能である. ただし，前述の理由により低域ではショットガンマイクロ ホンでも狭指向性が得られない.

そこで，低域についてのみ，図4に示すようにショット 


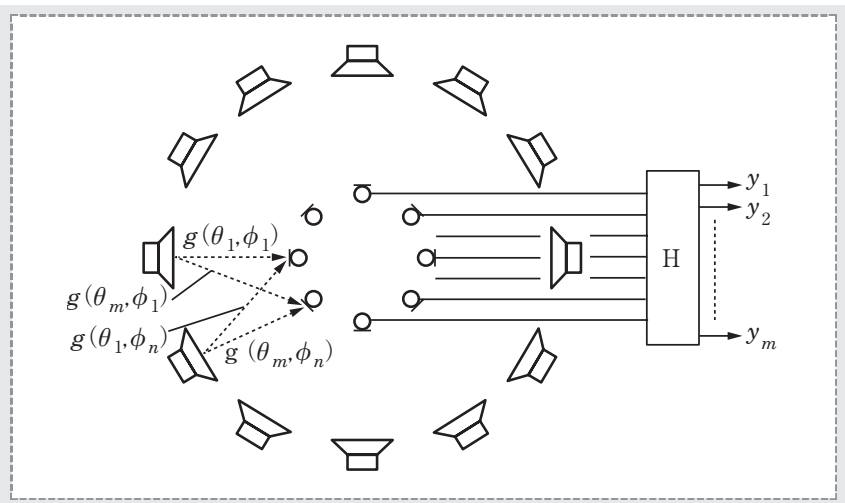

図4 ショットガンマイクロホンアレイによる

指向性合成処理

高域：ショットガンマイクロホン信号をそのまま出力 低域：音場の逆フィルタ処理 $\mathrm{H}$ を行い指向性制御を行う

ガンマイクロホンの複数の素子を組合せて音場の逆フィル 夕処理による指向性制御を行い, 広い帯域で狭指向性を得 る手法が提案されている ${ }^{2)}$. 本手法は, 任意の向きへの指 向性制御には不向きであるが，あらかじめチャネル配置が 既知であるマルチチャネル音響において, マイクロホン素 子数を一定に抑えることが可能である.

\section{3 音場の方向情報に基づいた記録手法}

狭指向性により音波の方向を物理的に分離する手法をと らず，全指向性の (方向性を持たない) 音を収音すると同時 に，時々刻々の方向情報を同時に計測・収録し，この二つ の情報を統合して 3 次元音響を記録する手法が知られてい る. DirAC (Directinal Audio Coding) 3) と呼ばれるこの手 法は，3軸のダイポールから構成されるマイクロホンアレ イ等を用い，図5に示すように各周波数帯ごとに時々刻々 の方向 (音響インテンシティベクトル) を計測・記録すると
ともに，同時に収音した方向情報を持たない音の振幅を合 わせて収音し，これらを統合して音場を再構成する方式で ある. 特定の短時間空の中で, 特定の周波数帯では, 方向 を 1 方向に限定するため近似の大きい方式であるが，極め て効率的に 3 次元音響を記録できると考えられ，3次元音 響の高効率な圧縮符号化などにも応用されている.

\section{4 残響付加}

制作における信号処理としては, 残響付加技術が重要で ある．空間の響きは一般に全方位から到来し，かつ方向ご とに無相関であり, この特徴が広がり感に大きく寄与して いる一方，上記の用件を満たす残響音を収音するためには， 多数のマイクロホンを間隔を離して設置することを必要と する.このため, 充分な質とチャネル数を有する残響音の 収音は必ずしも容易でなく, 残響付加装置によって制作時 に残響を付加する場合がある，また，異なる素材信号間の 残響感を揃えて，音をミックスした際により自然に聞こえ るための調整も, 残響付加装置の重要な役割である.

残響付加装置の基本的な構成としては, インパルス応答 をFIRフィルタとして重畳する方式 (以下 FIR 型) と, IIR フィルタを用いる方式 (IIR型) があるＦIR型は，優れた 音響特性を有する空間の残響音をより正確に再生できる一 方, 制作時に必要な調整が容易でない。一方, IIR 型は音 響的にはFIR 型ほどの正確さはないが，パラメトリックに 自在な調整が可能である. 番組制作では残響感の調整が重 要となること，処理コストが相対的に低いことから，残響 付加装置はIIR型が主流であった。

一方，ハードウェアの進歩により，FIRフィルタを用い るケースも増えつつある。特に $22.2 \mathrm{ch}$ 音響の制作では, FIR 型が開発され，番組制作に用いられている4）(図6). 本装置は残響特性の自在な調整は不可能であるが, 残響時

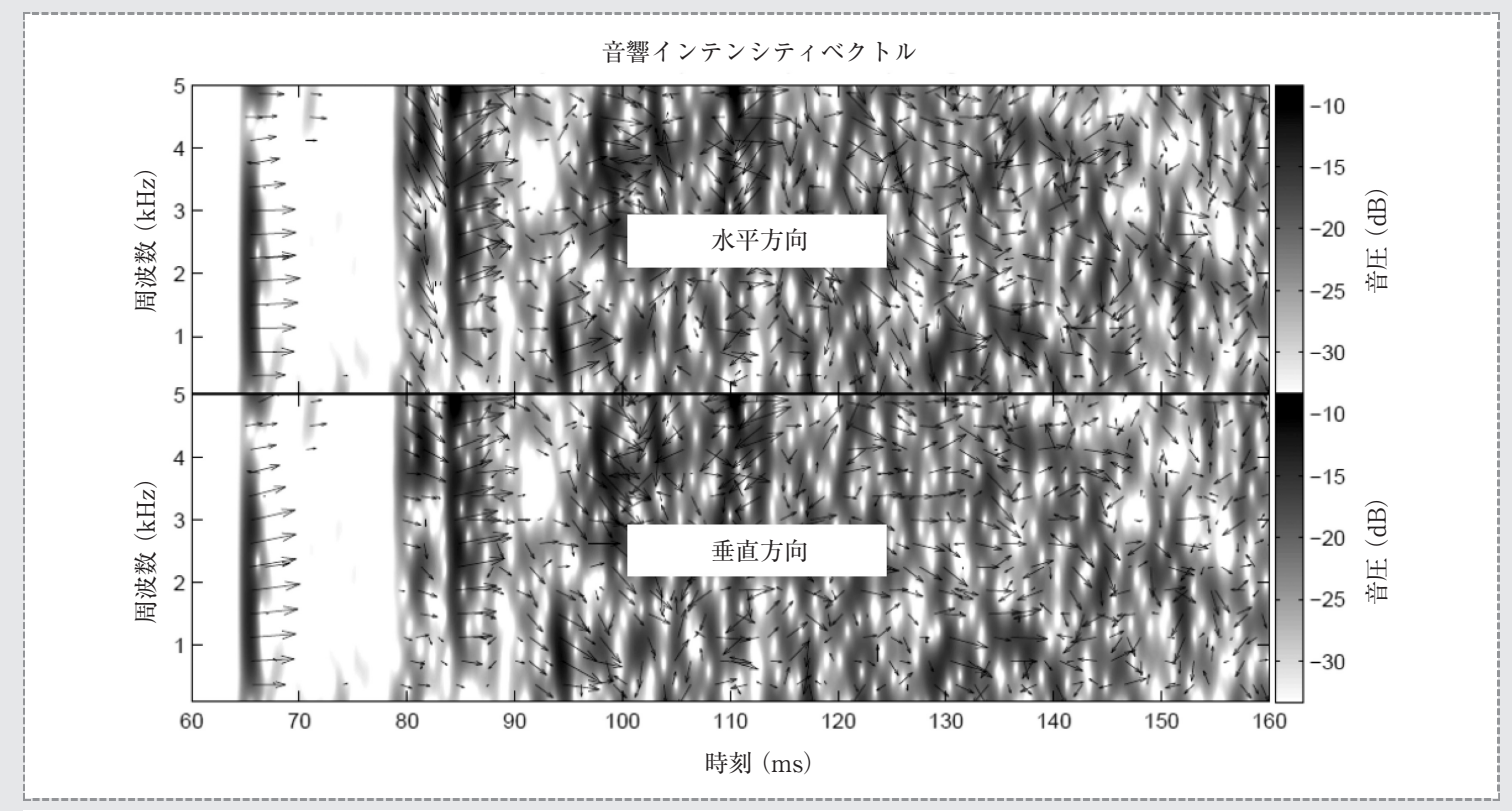

図5 DirACによる音場の表現 


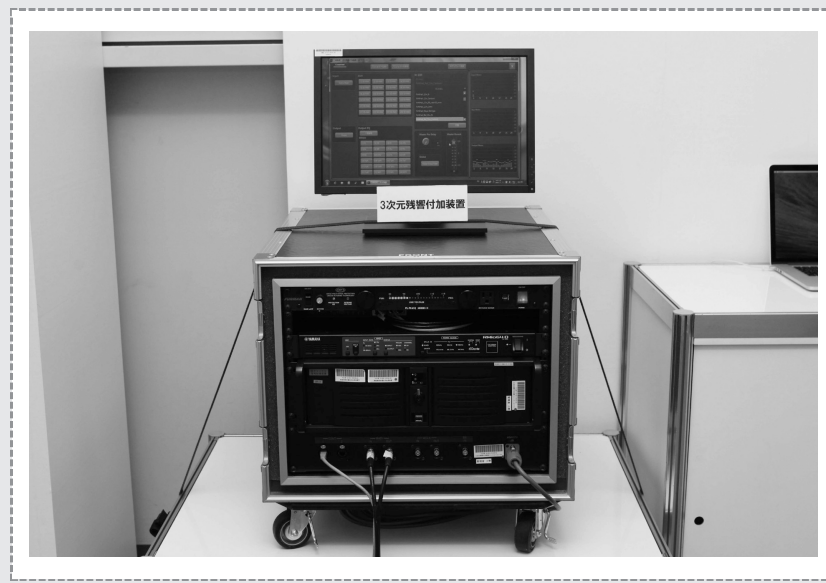

図6 22.2ch音響残響付加装置

間の短縮化については，実測したインパルス応答のエンベ ロープの減衰を早めることで連続的に可能である。一方， 残響時間の伸長はエンベロープの調整では困難なため, 残 響時間の伸長手法が新たにが提案されている5).

本伸長手法は，インパルス応答を空関数をかけてブロッ クに分割し，それを一定の規則のもとでランダムにシャッ フルすることで, 多数の応答を生成する手法である, ブ ロックシフト法を拡張したものである．従来のブロックシ フト法では, 生成する応答中のブロック数は既存の応答と 同数であったが，同一のブロックを複数回用いて再構成す ることで, 既存のインパルス応答の残響時間を伸長するこ とが可能である.

このようにして生成した, 例えば約 2 倍の長さの応答を ライブラリーとして残響付加装置内に入れておき, 前述の エンベロープの減衰と組合せることにより, 残響時間を連 続的に増減することが可能である. なお，ブロックシフト 法は本来, 音色が類似し, かつ互いに相関の低いインパル ス応答を多数生成する機能も有するため, 上記の残響時間 の調整だけでなく, $2 \mathrm{ch}$ や $5.1 \mathrm{ch}$ のインパルス応答をもとに, $22.2 \mathrm{ch}$ のインパルス応答を生成する機能も有し, ライブラ リーの拡充に貢献している技術である.

\section{5 バイノーラル再生}

3 次元音響のアプローチとして, 本稿ではスピーカ再生 を基本とする音場再生技術について述べたが，バイノーラ ル再生技術も重要である. バイノーラル再生とは, 人間の 耳が二つであるので，人間の両耳の位置の音情報を再現す れば，すべての音情報は，人間にとって必要充分であると いう考え方に基づく，その技術の基本は，人間の耳に取り 付けたマイクロホン，もしくは人間の頭の形をしたマネキ ン(ダミーヘッド)の耳の位置に取り付けたマイクロホンで 収音し，これをへッドホンやイヤホンにより再生するもの である。

マルチチャネル音響をヘッドホン再生する場合は, 各 チャネルの信号ごとに, そのチャネルの方向の頭部伝達関
数をたたみ込んでヘッドホン信号を生成することにより可 能である.より安定した定位感を得るために, 頭部運動を 補償した音響再生も試みられている。

一方，バイノーラル信号をスピーカから再生することが できれば，ヘッドホンを用いることなくバイノーラル再生 を楽しむことができる。一般にスピーカから放射される音 は左右の両耳に入るため，2チャネル以上の信号を前処理 し，右耳用の信号が反対耳 (左耳) に入らないようにする逆 フィルタ処理が必要となる.

本技術は，古くは 2 チャネルのクロストークキャンセル 問題として提案されたが, 近年では逆フィルタを安定化す る目的で再生するスピーカの幅を音波の波長にあわせて変 化させる方式 6$), 22.2 \mathrm{ch}$ 音響のディスプレイ一体型スピー カとして 12 個のスピーカにより再生する方式7) 等が開発さ れている.

\section{4. むすび}

音楽再生の高品質化にかかわる技術について述べた。こ こでは紹介できなかったが，記録や伝送に用いる圧縮技術 の進歩も, 音楽再生の高品質化には不可欠の要素である.

今回主として取り上げた $22.2 \mathrm{ch}$ 音響は, $8 \mathrm{~K}$ スーパーハイ ビジョン用の音響方式として，すでに試験放送が行われて いる．ワールドカップや五輪などの主要なスポーツイベン トなどと並んで, 多様な魅力ある音楽コンテンツが人気を 博している.

今後も音響信号処理技術の発展により, 魅力ある音楽コ ンテンツがさらに広まることを願いたい.

(2017年6月 2 日受付)

\section{〔文 献〕}

1）小野：“マルチチャネルオーディオ”，映情学誌，68，8，pp.604-607 (2014)

2）佐々木ほか：“音場の逆フィルタ処理に基づくマルチチャネルワンポ イントマイクロホンについて〜指向性マイクロホン素子による検討 〜”，2015年秋季日本音響学会研究発表会講演論文集，577-578（2015）

3) V. Pulkki: "Spatial Sound Reproduction with Directional Audio Coding", J. Audio Eng. Soc., 55, 6, pp.503-516 (2007)

4）西口ほか：“8Kスーパーハイビジョン $22.2 \mathrm{ch}$ 音響制作システムの開 発”，映情学技報，38，44，BCT2014-89,pp.77-81（2014）

5）森ほか：“ $22.2 \mathrm{ch}$ 音響制作のための多数の残響音生成手法の検討－残 響時間の調整-”2016年春季日本音響学会研究発表会講演論文集, p.789-790 (2016)

6）武内：“スピーカを用いたバイノーラル立体音響再生”，日本音響学 会誌，61，7，pp.398-403（2005）

7）松井ほか：“22.2マルチチャネル音響の枠型スピーカによるバイノー ラル再生法の開発”, 映情学誌, 70, 1, pp.J37-J46（2016）

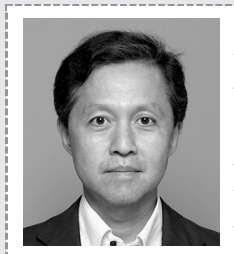

小野 一穂 1991 年, 東京大学工学部計数工学科 修士卒業. 同年, NHK入局. 以来, 放送技術研究所 にて，音響トランスデューサ，3次元音響の研究， ARIB 標準化活動等に従事. 市村学術賞, 日本音響学 会技術開発賞, 関東地方発明表彰発明奨励賞, 放送文 化基金賞, IEEE GCCE2016 Excellent Paper Award 1st Prizeなどを受賞. 正会員. 